\title{
9. Contemporary Migration Within the Pacific Islands: The case of Fijian skilled workers in Kiribati and Marshall Islands
}

\section{Avelina Rokoduru}

Contemporary skilled migration from Fiji to other Pacific Island countries began in the early 1980s and has continued since. There are Fijian citizens who work as domestic help as well as in the hotel industry in Cook Islands, and there are nurses, teachers, doctors, lawyers, pilots, mechanics, electricians and technicians in the Federated States of Micronesia, Guam, Kiribati, Marshall Islands and Vanuatu. With the coming of the Regional Assistance Mission to Solomon Islands in 2003, we have seen policemen and women moving to Solomon Islands. What is more, the trend is likely to continue if the Pacific Plan, which envisages greater labour mobility among Pacific Islands Forum countries, becomes reality. This paper provides a detailed discussion of the Fijian migrants in the Marshall Islands and Kiribati to illustrate this new phenomenon of intra-regional skilled migration from Fiji.

\section{A profile of the Fijian migrants}

There were 49 Fijian labour migrants who were interviewed in the Marshalls and Kiribati. Of these, 37 per cent were males and 63 per cent were females. By ethnic division, 77 per cent were native Fijians, 15 per cent were Indo-Fijians, 4 per cent were Rotumans and the remaining 4 per cent included Rabians (Fiji-born Gilbertese) and a naturalised Filipino resident. The Fijian migrants in this study have lived a minimum of one to a maximum of 37 years in their Pacific Island destination. The ages of the migrants ranged from 22 to 65 years with 22 per cent of the migrants in their 20s, 32 per cent in their thirties, 28 per cent in their forties and about 18 per cent in their fifties and sixties. The average age was 26 years; therefore, the majority of the migrants were well within the active working-age group of 20 to 50. Finally, their religious affiliation varied between Christian denominations (92 per cent), Hinduism ( 6 per cent), and the remaining two per cent were Buddhists.

The number of years of work experience for the Fijian migrants in the Marshall Islands ranged from three to 40 years in Fiji before their departure. On the other hand, the Fijian workers on Tarawa, Kiribati, had accumulated one to 19 years of work experience in Fiji before their migration. On the whole, the Fijian migrants are indeed experienced and skilled in their various professions. 
The migrants worked in various occupational categories ranging from civil servants in Kiribati to government physicians in the Marshalls. Other types of jobs taken up by Fijian migrants included bartender, dental therapist, dentist, domestic worker, hotel worker, kindergarten teacher, lawyer, physician and shipping officer. The majority of these job categories required a specific level of academic competence, which was fulfilled by the migrants in this study.

Table 1: Occupational categories for Fijian migrants by sex in Kiribati and Marshall Islands, 2002.

\begin{tabular}{|c|c|c|c|c|c|}
\hline $\begin{array}{c}\text { Occupational } \\
\text { category }\end{array}$ & \multicolumn{2}{|c|}{ Marshall Islands (\%) (No.) } & \multicolumn{2}{c|}{ Kiribati (\%) (No.) } & Total (\%) (No.) \\
\hline & Males & Females & Males & Females & \\
\hline Hotel workers & 2 & 4 & 0 & 0 & 6 \\
\hline Mechanics & 2 & 0 & 4 & 0 & 6 \\
\hline Nurses & 2 & 31 & 0 & 0 & 2 \\
\hline $\begin{array}{c}\text { Kindergarten } \\
\text { teachers }\end{array}$ & 0 & 2 & 0 & 0 & 14 \\
\hline $\begin{array}{c}\text { Primary teachers } \\
\text { Secondary } \\
\text { teachers }\end{array}$ & 6 & 8 & 0 & 0 & 27 \\
\hline Lawyers & 2 & 12 & 2 & 0 & 2 \\
\hline $\begin{array}{c}\text { Dentists and } \\
\text { therapists }\end{array}$ & 0 & 0 & 0 & 2 & 4 \\
\hline Civil servants & 0 & 0 & 0 & 2 & 2 \\
\hline Others & 0 & 2 & 0 & 0 & 2 \\
\hline Total & $27(13)$ & $61(30)$ & $6(3)$ & $6(3)$ & 100 (49) \\
\hline
\end{tabular}

Note: The Fijian migrants worked at various places in their host countries. The percentages are calculated to the nearest whole number.

Source: Fieldwork data from Kiribati and Marshall Islands, June-August, 2002.

About 90 per cent of the migrants indicated tertiary education as the highest level of education they had attained, and worked in the civil service, or as bartenders, kindergarten teachers, primary and secondary schoolteachers, nurses, doctors and dental therapists, lawyers and shipping officers. The remaining 10 per cent of the workers stated reaching only secondary school-level education. These migrants worked as mechanics and hotel workers in Kiribati and Marshall Islands, respectively.

Table 2: Academic qualifications of Fijian skilled migrants in Kiribati and Marshall Islands, 2002.

\begin{tabular}{|c|c|c|}
\hline Academic qualification achieved & Marshall Islands (\%) (No.) & Kiribati (\%) (No.) \\
\hline Certificate & 30 & 33 \\
\hline Diploma & 47 & 50 \\
\hline Degree & 21 & 17 \\
\hline Postgraduate diploma & 2 & 0 \\
\hline Total & $100(43)$ & $100(6)$ \\
\hline
\end{tabular}

Note: Only the highest academic qualification was considered for this question.

Source: Fieldwork data, Kiribati and Marshall Islands. June-August 2002. 
This group of Fijian labour migrants to Kiribati and the Marshalls was mostly female, mostly ethnic Fijians, young, skilled and experienced in their fields of occupation.

\section{Push factors for mobility out of Fiji}

There were various socioeconomic factors that motivated the migrants to travel to other Pacific Island countries for employment. These push factors have been tabled with the most important preceding the others.

Table 3: Reasons for departing from Fiji by order of importance.

\begin{tabular}{|c|c|c|c|}
\hline Reasons & Kiribati (\%) (No.) & Marshall Islands (\%) (No.) & Total (\%) (No.) \\
\hline $\begin{array}{c}\text { Inadequate pay/salary in } \\
\text { Fiji }\end{array}$ & 17 & 55 & 72 \\
\hline $\begin{array}{c}\text { Work conditions in Fiji not } \\
\text { good }\end{array}$ & 0 & 21 & 21 \\
\hline $\begin{array}{c}\text { A desire for a new living } \\
\text { and working environment }\end{array}$ & 17 & 2 & 19 \\
\hline Travel and adventure & 17 & 0 & 17 \\
\hline Political instability & 17 & 0 & 17 \\
\hline Other reasons & 50 & 26 & 76 \\
\hline Total & $118(7)$ & $104(45)$ & $222(52)$ \\
\hline
\end{tabular}

Note: This is a multiple response question and percentage totals might be more than 100.

Source: Fieldwork data from Kiribati and Marshall Islands, June-August 2002.

The most important motivation for the Fijian migrants was that pay offered locally was inadequate compared with what they were being offered in their host countries. For instance, a Fijian graduate secondary schoolteacher working regular hours between $8.30 \mathrm{am}$ and $4.30 \mathrm{pm}$ was being paid $\$ F 13,000$. The same teacher could earn \$A20,000 (\$F34,000) at a secondary school in the Marshall Islands.

Other reasons for leaving Fiji were to accompany a spouse or relatives, that there was more need for their skill in the host country, that it was a divine calling to serve, to move out of the country because of retirement, to facilitate immigration to metropolitan countries, to avoid the racial discrimination experienced in Fiji, because chances for promotion in Fiji were slim, as well as the opportunity to be near parents. These results reflect the work of Leweniqila and others (2000: 7), who noted that 'the nightingales' were leaving Fiji for other countries, including other Pacific Island countries, to work, due to poor work conditions, a very low salary scale and poor management of those in the nursing profession.

On the other hand, except for one response noting racial discrimination as a push factor in this study, the results generally depart from the conclusions reached by Mohanty (2001: 58). He argues that the key push factors for Indo-Fijian migration are social and economic insecurities arising from land tenure problems; fear of political uncertainty and insecurity; discrimination; rural terrorism and problems of law and order; and the continuing political and 
constitutional crises. The racial profiles of the two studies explain much of this difference in motivating factors for labour migration. Indo-Fijians leave Fiji for different reasons than Fijians.

\section{Contracts}

The labour contract, a formal agreement between employer and employee over critical labour and living conditions, provides the framework around which everything else that concerns that relationship revolves. In this study, the contracts and terms of conditions were very important because 72 per cent of the respondents indicated that these had influenced their decision to find employment in Kiribati and the Marshall Islands. Employment contracts for the nurses and teachers in both countries generally varied between two- to three-year terms, which were renewable annually after the successful completion of the first term, or contracts were reviewed annually and renewed as negotiated by the employers and the Fijian migrant. For instance, for teachers in the Marshalls, employment begins with a probationary period, which lasts for the first 12 months of the two-year contract. Wages are paid fortnightly in 26 pay periods a year, for which 10 months are basically for teaching work. The remaining two months are allocated for national holidays, including a spring and semester break.

The Marshall Islands is an independent republic which was under American occupation and subsequent administration from 1943 to 1979. The Marshalls became self-governing in 1979 and independent in 1986, entering into a Compact of Free Association with the USA, which retains long-term control over the Marshalls' defence and economy. The compact has recently been renewed. Given that history, the Marshalls' currency is the US dollar and is generally twice as strong as the Fijian dollar. This currency differential is an added bonus for the Fijian migrants.

For instance, registered nurses in Fiji generally start at the salary level of a staff nurse at $\$ F 10,920$, which increases gradually to $\$ F 15,409$ by the time they have worked for at least 12 years in the service (FNA 2002: $62^{l}$ ) and at least 87 per cent of Fiji's nurses fall into this salary category. In this study, 90 per cent of the nurses who moved to Kiribati and the Marshalls were qualified staff nurses from Fiji. On arrival in the Marshall Islands, the salary scale of the Fijian nurses began at $\$ U S 18,000$ ( $\$ A 24,000)$, an equivalent of about $\$ F 40,000$. This represented a huge increase for women who were still working as staff nurses. It meant that staff nurses working in the Marshalls were receiving the equivalent of the salary of the Principal of the Fiji Nursing School, or more. Indeed, the salary differentials in this case were too overwhelming to resist. 


\section{Table 4: Fijian nurses - salary levels by ranges by percentage of nursing} positions, 2002.

\begin{tabular}{|c|c|c|}
\hline $\begin{array}{c}\text { Fijian nursing positions and } \\
\text { percentage of nurses in workforce } \\
\text { in Fiji }\end{array}$ & $\begin{array}{c}\text { Fijian salary range \$F } \\
\text { (approximate) }\end{array}$ & $\begin{array}{c}\text { Marshall Islands salary range \$US } \\
\text { (\$F equivalent) }\end{array}$ \\
\hline $\begin{array}{c}\text { Principal, Fiji School of Nursing } \\
\text { (FSN) }-\mathbf{0 . 0 1 \%}\end{array}$ & $32,802-42,424$ & - \\
\hline $\begin{array}{c}\text { Senior matron and Vice-Principal } \\
\text { (FSN) -0.02\% }\end{array}$ & $24,939-32,266$ & - \\
\hline Senior nursing tutors - 1\% & $19,166-24,813$ & - \\
\hline $\begin{array}{c}\text { Senior sisters and nursing } \\
\text { practitioners - 8.9\% }\end{array}$ & $16,260-19,639$ & - \\
\hline Sisters - 3\% & $13,920-16,917$ & $\begin{array}{c}18,000-25,000 \\
(40,659-56,471)\end{array}$ \\
\hline Staff nurses - 87\% & $10,920-15,409$ & \\
\hline
\end{tabular}

Note: Conversions based on May 2002 exchange rates.

Source: Fiji Nursing Association 45th Annual General Meeting Report, March, 2002, p. 62.

In the case of teachers in Fiji, the starting salaries of graduate teachers began at $\$ F 17,283$ and increased gradually to $\$ F 39,516$ for principals (PSC 2003). Yet, the Fijian teachers in the Marshall Islands generally started at about \$US16,380 (\$A22,072), the equivalent of about $\$ F 37,000$. Therefore, the starting salary of an assistant secondary schoolteacher in the Marshalls was equivalent to that of a principal at a secondary school in Fiji. The issue of yearly increases and bonuses for the teachers in the Marshalls has not been factored into the salaries considered above. In this case, the salary differentials again were too good to resist for the Fijian migrant teachers in this study. Consequently, about 51 per cent of the total migrants indicated their salary differentials as a distinct advantage of their migration.

Table 5: Fiji/Marshall Islands teachers - salary levels by position, 2003.

\begin{tabular}{|c|c|c|}
\hline Teaching position & $\begin{array}{c}\text { Fiji salary level and ranges \$F } \\
\text { (approximate) }\end{array}$ & $\begin{array}{c}\text { Marshall Islands salary level and } \\
\text { range \$US (equivalent to \$F net - } \\
\text { approximate) }\end{array}$ \\
\hline Principals (secondary) & $28,293-39,516$ & - \\
\hline Vice-Principals (secondary) & $25,937-32,562$ & - \\
\hline Assistant principals (secondary) & $21,397-30,415$ & - \\
\hline Heads of departments (secondary) & $21,397-25,103$ & $16,380-19,000$ \\
\hline $\begin{array}{c}\text { Assistant teachers (secondary) } \\
\text { University graduates with teaching } \\
\text { certificates }\end{array}$ & $17,283-20,006$ & $(37,000-42,918)$ \\
\hline $\begin{array}{c}\text { Assistant teachers (secondary) Fiji } \\
\text { College of Advanced Education } \\
\text { Diplomas }\end{array}$ & $15,126-19,010$ & - \\
\hline Head teachers (primary school) & $24,971-33,996$ & $33,800(76,349)$ \\
\hline $\begin{array}{c}\text { Assistant teachers (primary school) } \\
\text { B.Ed. university graduates with } \\
\text { teaching certificates }\end{array}$ & $17,283-19,056$ & $11,960-14,000$ \\
\hline $\begin{array}{c}\text { Assistant teachers (primary school) } \\
\text { Diplomas with teaching certificates }\end{array}$ & $12,990-15,126$ & $(27,016-31,624)$ \\
\hline Kindergarten teachers & 14,000 & $7,280-11,960$ \\
\hline
\end{tabular}

Note: July 2002 exchange rates.

Source: Public Service Commission, 2004, 2003 Civil List - Making A Difference, Suva: PSC. 
All the Fijian women in this study were paid on a fortnightly basis according to their contracts. About 18 per cent of them were able to graduate to a higher scale of pay (apart from the regular increments), while 82 per cent remained on the initial salary scale they had been hired at. The main reason for the stagnation of the women's salary scale was that the women had just started working in their host country. Most of the women who had received salary increases had received them only once at the time of this research with the exception of a woman who had received three increases, in 1994, 1995 and in 2002. She was working as a nurse at the time of this study. As well, about 53 per cent of the women also received the 13th salary (a mandatory annual year-end additional monthly salary ${ }^{2}$ ) even though it was not specifically stated in their contract, while 47 per cent could not say whether they received this salary as they were not aware of the concept. The 53rd-week salary (which applied only to people paid weekly and only for times when the work year had 53 weeks), did not apply to the migrant women as they were receiving fortnightly pay.

The majority of the migrants enjoyed medical benefits. For instance, about 83 per cent of the Fijian women received free or subsidised medical coverage depending on the seriousness of each medical case. The nurses in the Marshalls indicated receiving free medical treatment was part of their package, excluding illnesses that needed special medical attention. The latter medical needs are met by their employers and subsidised by the health insurance scheme the nurses are affiliated to. On the other hand, 12 per cent of the women workers indicated not being included in any medical coverage (hotel workers and a maid) and 5 per cent of the women were not aware of this benefit being granted them.

All the teachers in the Marshalls are included in the Group Health Insurance scheme for civil servants, receive sick leave and personal leave, and can be awarded compensation for on-the-job injuries. They are also eligible for medical care at 7 per cent of their gross earnings - a sum divided equally between the employer and the migrant teacher.

The employers also provided either a housing allowance or accommodation for the duration of the contract, as well as return transportation costs for the migrant and his/her family and possessions from the point of hire to the Marshalls and Kiribati at the successful completion of a contract. The teachers at the University of the South Pacific-Republic of the Marshall Islands Joint Project were provided free daily transport to and from work. On the other hand, the teachers working at Church of God High School in Tarawa, Kiribati, lived in the school compound and did not need transport, though this was provided for medical trips to the hospital. Meanwhile, nurses living on Kwajalein (a US military base) were provided with daily ferry and taxi tickets to and from the Ebeye Hospital where they worked, whereas the nurses living on Majuro were provided with subsidised transport to and from the hospital. Travel and meal allowances were paid out 
during night shifts, which also involved a special pay rate, and about 82 per cent of the Fijian women migrants were given transport to and from work, the majority of whom (59 per cent) enjoyed subsidised transportation paid for by their employers.

\section{Case study one: Fijian migrants' salaries at Ebeye Health Clinic, Marshall Islands, 2002}

In Fiji, a staff nurse receives an average monthly income of $\$ F 312.20$, compared with \$US660 (\$A889) in the Marshall Islands, which is the equivalent of some $\$ F 1,490$ a month. The Fijian and Marshall Islands nurses' salaries were paid fortnightly and the difference in amounts was substantial. Case study one: Salaries for Fijian migrant health workers, Ebeye Health Clinic, 2002 (from fieldwork data, July-August 2002.) Occupation at Ebeye Health Clinic Monthly net (\$US) Equivalent (\$F)

Case study one: Salaries for Fijian migrant health workers, Ebeye Health Clinic, 2002.

\begin{tabular}{|c|c|c|}
\hline Occupation at Ebeye Health Clinic & Monthly net (\$US) & Equivalent (\$F) \\
\hline Staff nurse & 660 & 1,490 \\
\hline Staff nurse & 684 & 1,545 \\
\hline Staff nurse & 800 & 1,807 \\
\hline Staff nurse & 1,067 & 2,410 \\
\hline Staff nurse & 1,200 & 2,710 \\
\hline Staff nurse & 1,170 & 2,642 \\
\hline Dental officer & 4,000 & 9,035 \\
\hline Staff physician & 6,044 & 13,652 \\
\hline
\end{tabular}

Note: The medical personnel from Fiji received attractive packages from the Health Administration in Ebeye. Source: Fieldwork data, July-August 2002.

Where housing or allowances were provided, additional costs for house renovations and furniture needs and maintenance were fully met by the employer. Other costs such as domestic bills including compound upkeep, water, electricity, gas and telephone were either subsidised or fully met by the employer.

I live with my employers in the basement of the hotel and they are generous to me. I am provided accommodation, and free electricity, water, phone and house furnishings. So I just buy food and clothes. (Hotel worker, interview, August 2002)

About 94 per cent of the Fijian migrants enjoyed paid annual leave ranging from two weeks to two months for teachers, with the exception of the people who worked as missionaries. On the other hand, about 87 per cent of the women stated that they were entitled to paid annual leave while 2 per cent indicated otherwise. The remaining 11 per cent were not aware whether they had this benefit. This group included the women working at a local hotel and in the mission field in the Marshalls. 
For those women who enjoyed paid annual leave, leave lengths ranged from two to six weeks a year. Meanwhile, about 24 per cent of the women migrants were given maternity leave by their employers as a benefit. A further 35 per cent stated they were not awarded this benefit, while 12 per cent were not aware of this benefit. The remaining 29 per cent did not state whether this benefit was included in their contracts.

We came on the understanding to come and work, not to come and get pregnant. We are not expected to get pregnant while working here. (Nurse 12, interview, July 2002)

The superannuation schemes considered in this study included provident and pensions funds for the migrants. All the migrants deducted funds from their salaries for these schemes but only a few have enjoyed their benefits. The Fijian workers in Kiribati received superannuation at the end of their contracts, whereas only those migrants who had turned 55 years of age received their benefits in the Marshalls. The latter had fulfilled the conditions that dictated that migrant workers could receive their provident and/or pension refunds only upon the age of 55 and must be physically present in Majuro to receive their refund cheques.

Therefore, for the Fijian women in the Marshalls, only 41 per cent indicated the provident fund as a benefit, while 59 per cent said it was not a benefit at all. They thought the schemes were counterproductive as they had no intention of working in the Marshalls until the age of 55. Therefore, they were being denied funds they had rightfully earned and would most likely lose because the total expenses involved in returning to receive a cheque would be much higher than the refund itself. This response was another indication that this form of migration was only temporary and short-term for most of the migrants.

A mere 6 per cent of the women had enjoyed a promotion at their workplace. The subjects had received their promotion in 1999 and 2000 respectively. Further, the majority of the women did not know the prospects for promotion at their workplaces if they worked for a period of five years. It can be concluded that job promotions depended on the status of the migration (in this case, it was temporary) and the availability of local skilled labour in the host country.

\section{Remittances}

Generally, migrant remittances refer to any form of goods sent from the migrants to a receiving country. Remittances are usually perceived to be a one-way flow from the migrant to recipients but this is not so for this study, as will be discussed in this section.

Most Fijian migrants in Kiribati and the Marshalls sent something home to Fiji. 92 per cent sent money, 63 per cent also sent gifts of clothes, and food (6 per 
cent). Many of the migrants sent money home regularly (54 per cent), while 21 per cent sent home money only on request. Regular remitters sent money to Fiji every fortnight when they received their salaries. A further 17 per cent sent money home only for special occasions, for example, birthdays, and to assist on the death of a family member. Eight per cent of the respondents chose not to answer this question. The amount of cash remittances sent home ranged from \$A134 to \$Al,644 fortnightly - for the 71 per cent of the respondents who chose to answer this. There was an isolated case of a respondent sending home $\$ A 3,234$ to assist the family after the death of a relative.

Table 6: Fortnightly monetary remittances sent by Fijian migrants by host country, 2002.

\begin{tabular}{|c|c|c|c|}
\hline $\begin{array}{c}\text { Amount of money sent } \\
\text { fortnightly }\end{array}$ & Marshall Islands \% (No.) & Kiribati \% (No.) & Total \% (No.) \\
\hline$\$ 0-100$ & 53 & 66 & 55 \\
\hline$\$ 101-200$ & 3 & 0 & 5 \\
\hline$\$ 201-300$ & 6 & 0 & 11 \\
\hline$\$ 301-400$ & 8 & 17 & 5 \\
\hline$\$ 401-500$ & 6 & 0 & 2 \\
\hline$\$ 501-600$ & 8 & 0 & 2 \\
\hline$\$ 601-700$ & 3 & 0 & 5 \\
\hline$\$ 701-800$ & 3 & 0 & 2 \\
\hline$\$ 801-900$ & 6 & 0 & 2 \\
\hline$\$ 1,000-1,200$ & 0 & 17 & 2 \\
\hline$\$ 1,201-1,300$ & 3 & 0 & $100(42)$ \\
\hline$\$ 2,400$ & 3 & 0 & $100(6)$ \\
\hline Total of respondents & $100(36)$ & & 2 \\
\hline
\end{tabular}

Note: Remittances were sent fortnightly to family members, friends, academic and financial institutions. Soucre: Fieldwork data from Kiribati and Marshall Islands, June-August 2002.

Up to 23 per cent of the respondents sent monetary remittances to their children while 19 per cent sent remittances to their spouses. The majority ( 27 per cent) sent remittances to their parents because they were looking after the children of the migrants in Fiji, and another 6 per cent sent monetary remittances to the Housing Authority of Fiji and home finance providers for housing properties they had invested in. A few respondents made direct payments to educational institutions for school fees, settled car loans, paid for life insurance schemes and paid domestic bills for electricity and telephone services. Sisters and other relatives (17 per cent) also received monetary remittances from the migrants.

There was an active exchange of goods and money between the migrants in their host countries and their families and friends back home in Fiji. The majority (80 per cent) of the Fijian subjects asked for things that were not available in their host destinations to be sent from home. These were mostly for their personal consumption. 
Table 7: Money and other items received from Fiji.

\begin{tabular}{|c|c|}
\hline Kiribati & Marshall Islands \\
\hline $\begin{array}{c}\text { Curry powder, chillies, spices, tinned tuna, baked taro } \\
\text { and cassava, kava, baby products, traditional artefacts } \\
\text { (mats, tapa, salusalu), Fijian scented oils, Fijian and } \\
\text { Hindi music and other language entertainment } \\
\text { audiotapes and other entertainment audio, CDs, videos } \\
\text { and DVDs, money }\end{array}$ & $\begin{array}{l}\text { Clothes, kava, snacks, cosmetics, kitchenware, } \\
\text { crochet string, custard powder, root crops, curry } \\
\text { powder, chillies, spices, pocket-sulus, yams, cassava, } \\
\text { taro, baby products, tea, traditional artefacts (mats, } \\
\text { tapa, salusalu), Fijian scented oils, sandals, Fijian } \\
\text { music and other entertainment audiotapes, CDs, } \\
\text { videos and DVDs, money }\end{array}$ \\
\hline
\end{tabular}

Note: There were regular two-way exchanges of money and items between the migrants and their families and friends in Fiji.

Source: Fieldwork data, 2002.

Most of the items were sent by postal courier or taken by people passing through Kiribati and the Marshall Islands. The migrants would send money and related instructions for particular expensive items such as kava and scented oil, while the other items were either sent across at regular intervals or packaged and taken across by Fijian travellers to those Pacific Island countries. The networks were well established between the migrants, their relatives, friends and co-workers and especially with the contact points (Fijian citizens), who regularly travelled the region working for regional institutions, private businesses or NGOs. These contact points became messengers and couriers between the migrants and Fiji.

\section{Case study two: Remittances of Fijian nurses in Ebeye, Marshall Islands}

The nurses sent money, clothes and other gift items to Fiji. In monetary terms, the seven nurses who answered this survey remitted between \$US266 (\$A358) and \$US890 $(\$ A 1,199)$ to Fiji in a fortnight from the local Western Union office. This would be the equivalent of $\$ F 600$ to $\$ 2,010$ a fortnight. The money was sent to families, friends and institutions.

Table 8: Cash remittances sent by Fijian nurses, Ebeye Health Clinic, 2002.

\begin{tabular}{|c|c|c|}
\hline Approximates \$US & Fijian equivalent \$F & No. of nurses \\
\hline $\mathbf{2 6 6}$ & 600 & 1 \\
\hline $\mathbf{2 6 7}$ & 603 & 3 \\
\hline $\mathbf{3 5 6}$ & 804 & 1 \\
\hline $\mathbf{4 4 4}$ & 1,002 & 1 \\
\hline $\mathbf{8 9 0}$ & 2,010 & 8 \\
\hline Total: $\mathbf{2 2 2 3}$ & 5019 & \\
\hline
\end{tabular}

Source: Fieldwork data, July-August 2002.

These remittances were sent to parents and/or spouses in order to pay for general family subsistence, for the welfare of their children and to meet telephone, water, electricity and gas bills, home, car and other property loans, school and medical fees and other traditional obligations in Fiji 


\section{Legal aspects of work and travel}

There is a need to establish the legal status of the Fijian migrants in this section. Kassim (in Toh Thian Ser 1998: 68), ${ }^{3}$ while discussing contemporary migration within and from South-East Asia, has classified immigrant workers into two categories: they are either legal or illegal. But the line demarcating the two can be very blurred and the two categories can become interchangeable. At the same time, an alien might enter a country legally but work there illegally, without a work permit.

While Kassim also elaborated on what illegal workers were, this paper will focus mainly on his definition of a legal alien as it closely identifies with the labour migrant situation being discussed here. Therefore, according to Kassim, ${ }^{4}$ alien workers are regarded as legal when they conform to the immigration and labour laws of the host country. Further, they can be recruited in two ways: 1) they might have been recruited directly from the sending countries, brought in through authorised ports of entry and given temporary work permits; or 2) they might have arrived illegally and worked without employment permits but were later regularised through an amnesty exercise.

In the context of this research, most of the Fijian labour migrants (89 per cent) were recruited in Fiji by recruiting agents or government officials for various government ministries of the host countries (50 per cent), private schools and tertiary institutions ( 21 per cent), businesses ( 12 per cent), and churches ( 6 per cent), and were taken into the host countries through authorised ports of entry. They were also granted temporary work permits or contracts of various lengths, from a minimum of two years up to indefinite periods. On the basis of Kassim's work, the labour migrants from Fiji represented in this study are legal alien workers. The remaining workers (11 per cent) had accompanied their spouses and were later recruited to work. They too were offered temporary work permits and contracts to allow them to work in Kiribati and the Marshall Islands.

Approximately 98 per cent of the skilled migrants were issued with work permits and these were granted either while still in Fiji (therefore, they signed on as expatriates with a different set of work conditions and salary scales) or on entry into their destination country. The latter were hired on a local contract basis, for example, some as teachers and government officials in Kiribati and some as nurses and teachers in the Marshalls:

I'm a civil servant. I just applied for the job, went on six months' probation and started work and I'm still here. (Dental therapist 33, interview, August 2002)

The length and validity of employment contracts varied from one year (8 per cent of the respondents), to two years (68 per cent), three years ( 6 per cent) or for even longer periods (18 per cent). Most of the nurses and teachers worked 
for two- or three-year terms before renewal (43 per cent) or are intending to return to Fiji (57 per cent) at the end of their current contract. The high percentages for renewals and the intention to return support the argument that Fijian labour migration to other parts of the Pacific is temporary and might be circular migration. This can be determined only by further studies.

Finally, 96 per cent of the respondents indicated that they did not pay a bond deposit to immigration officials at their entry point to destination countries. There has been a prevailing general attitude of acceptance of Fijian nationals entering other Pacific Islands on the strength of their Fijian passports alone. Therefore, Fijian nationals may enter certain Pacific Island countries without a formal visa if the length of their stay is less than a month. With current and future socioeconomic and political developments taking place in Fiji and within the region, this state of affairs might change. Indeed, the absence of a bond deposit and a month's visa-free visit for Fijian citizens encourages temporary migration to some Pacific Island countries and creates employment opportunities for those who are so inclined.

\section{Conclusion}

Skilled labour migration from Fiji to other Pacific Island countries is a new trend of migration whose future is yet to be mapped. While the main reasons for labour migration from Fiji to other metropolitan countries were based on economic and/or political insecurities, the main reasons for migration in this study were more economic and social in nature. While international migration (and labour migration at that) for Fiji is dominated by Indo-Fijians and is permanent or long term in nature, this study shows an opposite effect, where intra-regional skilled labour migration is dominated by ethnic Fijians and is temporary in nature.

The few differences discussed here regarding these patterns of labour migration bring the issue of ethnic tensions and differences in Fiji to the forefront. More research is needed in this field and other questions such as the social and economic costs of labour migration, other labour migrant communities, as well as return migration for Fiji still need to be studied.

Earlier studies focusing on Indo-Fijians identified insecurity and fear of the future, economic and political, as key motives for emigration from Fiji. My study, which focuses instead on indigenous Fijians, finds that they are emigrating to other parts of the Pacific not because of insecurity at home, but in order to make the most of better economic and social opportunities elsewhere, and that they have every intention of returning to Fiji.

What is more remarkable is that the temporary nature of this skilled migration (clearly spelt out in the legal provisions of travel and temporary work and in the generous contracts) is further supported by the prevailing socioeconomic environments and the geographical proximity of those countries to Fiji. Those 
conditions have provided a perfect scenario for temporary migration of skilled indigenous labour from Fiji to fulfil their socioeconomic aspirations in a most cost-effective manner. Based on this study, it seems that the success and future of this trend of intra-regional migration in the Pacific rests largely on one crucial aspect of temporary labour migration: that it remains just that - temporary.

\section{References}

Belloni, S. 2004. 'Fiji on the Way to Full Recovery?' Pacific Economic Bulletin, 19, 2. pp. 1-18.

Chand, A. and Vijay Naidu. 1998. 'Legal Aspects of International Migration in Fiji.' In Patrick Brownlee (ed.), Migration and Citizenship in the Asia-Pacific: Legal Issues, Working Paper No. 5, University of Wollongong: Asia-Pacific Migration Research Network. pp. 15-24.

Chagas, Carlos. 2004. What's Left to Cheer Brazil's Lula? Banks and Speculators. http://www.brazil.com-brazil

Chetty, N. K. and S. Prasad. 1993. 'Fiji's Emigration: An Examination of Contemporary Trends and Issues.' Demographic Report No. 4. Suva: School of Social and Economic Development, University of the South Pacific.

Connell, J. 2003. Draft Report on the Study of Migration of Skilled Health Personnel in the Pacific (Phase I). World Health Organisation, Regional Office for the Western Pacific.

Cox, David and Mary Low. 1985. Migration from the South Pacific: A Welfare Perspective. Melbourne: Department of Social Studies, University of Melbourne.

Fiji Nursing Association. 2002. Report of 45th Annual General Meeting, Tanoa International Hotel, Nadi, March 23.

Gani, Azmat. 2000. 'Some Dimensions of Fiji's Recent Emigration.' Pacific Economic Bulletin, 15, 1. pp. 94-103.

Leweniqila, M., L. Camaivuna and F. Dokoni. 2000. 'Why the Nightingales are Flying Away.' Nursing Research News, Pioneer Issues: 1.

Mohanty, M. 2001. 'Contemporary Emigration from Fiji: Some trends and issues in the post-independence era.' In V. Naidu, E. Vasta and C. Hawksley (eds), Current Trends in South Pacific Migration, Working Paper No. 7, Asia-Pacific Migration Research Network, University of Wollongong. pp. 54-73.

Toh Thian Ser (ed.). 1998. Megacities, Labour and Communications. Singapore: Institute of Southeast Asian Studies. 
Globalisation and Governance in the Pacific Islands

United Nations. 1997. International Migration and Development: The concise report. New York: Population Division, United Nations Secretariat.

\section{ENDNOTES}

1 Fiji Nursing Association 45th Annual General Meeting, Tanoa International Hotel, Nadi, March 23, 2002.

2 Carlos Chagas, 2004, What's Left to Cheer Brazil's Lula? Banks and Speculators, http://www.brazil.combrazil

3 Toh Thian Ser (ed.), 1998, Megacities, Labour and Communications, Singapore: Institute of Southeast Asian Studies, pp. 67-102.

4 Ibid., p. 68. 